\title{
ANTIHYPERLIPIDEMIC ACTIVITY OF SUAEDA MARITIMA (L.) DUMORTIER STEM IN TRITON INDUCED HYPERLIPIDEMIC RATS
}

Sumitra Singh, Rajinder mann* and Surendra Kr. Sharma

Department of Pharmaceutical Sciences, Guru Jambheshwar University of Science and Technology, Hisar, Haryana, India

Received on: 03/12/12 Revised on: 10/01/13 Accepted on: 12/02/13

\author{
*Corresponding author \\ E-mail: rajindermannchp@gmail.com \\ DOI: $10.7897 / 2277-4343.04222$ \\ Published by Moksha Publishing House. Website www.mokshaph.com \\ All rights reserved.
}

\section{ABSTRACT}

The present study was designed to investigate the hypolipidemic effect of Suaeda maritima (L.) Dumortier stem extracts in triton induced hyperlipidemia. Aqueous and alcoholic extracts of aerial parts of Suaeda maritima (L.) Dumortier were administered at dose $150 \mathrm{mg} / \mathrm{kg}$ and 300 $\mathrm{mg} / \mathrm{kg} /$ day orally, respectively. Simultaneous administrations of stem extracts of Suaeda maritima (L.) Dumortier significantly prevent the rise in serum levels of total cholesterol (TC), triglyceride (TG), Low density lipoprotein (LDL) and very low density lipoprotein (VLDL) whereas significant increases in the level of high density lipoprotein (HDL) in both secretary and excretory phase. The Suaeda maritima (L.) Dumortier methanol extract of stem at dose $300 \mathrm{mg} / \mathrm{kg}$ body weight orally showed significant antihyperlipidemic activity which may be due to the presence of triterpenoids and sterols found in the preliminary phytochemical screening.

Keywords: Suaeda maritima, Hypolipidemic activity, Hyperlipidemia.

\section{INTRODUCTION}

Elevated serum cholesterol levels leading to atherosclerosis can cause coronary heart disease ${ }^{1}$. Coronary arterial diseases are responsible for more deaths than all other associated causes combined. Hyperlipidemia characterized by elevated serum total cholesterol (TC), low density lipoprotein (LDL) and very low density lipoproteins (VLDL) and decreased high density lipoproteins (HDL) levels is the most prevalent indicator for susceptibility to cardiovascular disease ${ }^{2}$. World Health Organization reports that high blood cholesterol contributes to approximately $56 \%$ causes of cardiovascular disease worldwide and causes about 4.4 millions deaths each year. Hypercholesterolemia and hypertriglyceridemia are closely related to ischemic heart diseases $^{3}$. The main aim of treatment in patient with hyperlipidemia is to reduce the risk of developing ischemic heart disease or the occurrence of further cardiovascular or cerebrovascular disease ${ }^{4}$. Currently available synthetic hypolipidemic drugs have been associated with a number of side effects ${ }^{5}$. The consumption of synthetic drugs lead to hyperuricemia, diarrhea, nausea, myositis, gastric irritation flushing, dry skin and abnormal liver function ${ }^{6}$. Currently the use of complementary/alternative medicines and especially the consumption of phytochemicals have been rapidly increased worldwide. As herbal medicines are less damaging than synthetic drugs and they have better compatibility thus improving patient tolerance even on long term use ${ }^{7}$. Suaeda maritima (L.) Dumortier (Chenopodiaceae) is a salt marsh mangrove herb. The herb grows in very alkaline and saline moist soils. Locally it is called as Umiri in Pichavaram and Maltaumiri in Muthupet, Tamil Nadu, India. The raw or cooked young leaves has a pleasant salty flavor and mixed with other vegetable to reduce their saltiness.
Traditionally the leaf from Suaeda maritima (L.) Dumortier has been used as medicine for hepatitis and reported to have antibacterial activity and antioxidant activity $^{8-10}$. Various triterpenoids and sterols are present in the Suaeda maritima (L.) Dumortier ${ }^{1-12}$. The present study is aimed to assess the hypolipidemic potential of stem extract of Suaeda maritima (L.) Dumortier in Triton WR (1339) induced hyperlipidemia in rats.

\section{MATERIAL AND METHODS}

The plant of Suaeda maritima (L.)Dumort stem was collected during the month of September 2010 from Hisar (Haryana) North India. The specimen sample was taxonomically identified and authenticated by Dr.H.B.Singh, Head Raw Material Herbarium and Museum Division with Ref.No.NISCAIR/RHMD/ Consult/2010-11/1514/112. The voucher specimen has been deposited in the herbarium section of the Pharmacognosy Division, Department of Pharmaceutical Sciences, Guru Jambheshwar University of Science and Technology, Hisar for further reference. The plant stem were washed thrice with distilled water to remove the contaminants and dried in shade. The dried material was sliced into small pieces, pulverized using a mechanical grinder and stored in air tight container for further use.

\section{Preparation of Extracts}

The coarsely powdered sample $(500 \mathrm{~g})$ was defatted with petroleum ether $\left(60-80^{\circ} \mathrm{C}\right)$ and then extracted with methanol in soxhlet extractor for 72 hour. The aqueous extract was prepared by maceration with distilled water for 24 hour. Methanol and aqueous extract were concentrated in rotary vacuum evaporator. Dried extract were stored at $4^{\circ} \mathrm{C}$ for further use. 
Table 1: Effect of alcoholic and aqueous extracts of Suaeda maritima (I) Dumort. stem in triton induced hyperlipidemic rats

\begin{tabular}{|c|c|c|c|c|c|c|c|c|c|c|c|c|c|c|c|}
\hline \multirow[t]{2}{*}{ Groups SMS } & \multicolumn{3}{|c|}{ TC(mg/dl) } & \multicolumn{3}{|c|}{ TG(mg/dl) } & \multicolumn{3}{|c|}{ HDL(mg/dl) } & \multicolumn{3}{|c|}{ VLDL(mg/dl) } & \multicolumn{3}{|c|}{ LDL(mg/dl) } \\
\hline & $6 \mathrm{hrs}$ & $24 \mathrm{hrs}$ & $48 \mathrm{hrs}$ & $6 \mathrm{hrs}$ & $24 \mathrm{hrs}$ & $48 \mathrm{hrs}$ & $6 \mathrm{hrs}$ & $24 \mathrm{hrs}$ & $48 \mathrm{hrs}$ & $6 \mathrm{hrs}$ & $24 \mathrm{hrs}$ & $48 \mathrm{hrs}$ & $6 \mathrm{hrs}$ & $24 \mathrm{hrs}$ & $48 \mathrm{hrs}$ \\
\hline Normal & $\begin{array}{c}79.22 \pm \\
1.248\end{array}$ & $\begin{array}{c}79.22 \pm \\
1.248\end{array}$ & $\begin{array}{c}79.22 \pm \\
1.248\end{array}$ & $\begin{array}{c}88.746 \pm \\
1.475\end{array}$ & $\begin{array}{l}88.746 \pm \\
1.475\end{array}$ & $\begin{array}{c}88.746 \pm \\
1.475\end{array}$ & $\begin{array}{c}39.515 \pm \\
0.928\end{array}$ & $\begin{array}{c}39.515 \pm \\
0.928\end{array}$ & $\begin{array}{c}39.515 \pm \\
0.928\end{array}$ & $\begin{array}{c}17.749 \pm \\
0.295\end{array}$ & $\begin{array}{c}17.749+ \\
0.295\end{array}$ & $\begin{array}{c}17.749 \pm \\
0.295\end{array}$ & $\begin{array}{l}22.12 \pm \\
0.9407\end{array}$ & $\begin{array}{l}22.12 \pm \\
0.9407\end{array}$ & $\begin{array}{l}22.12 \pm \\
0.9407\end{array}$ \\
\hline $\begin{array}{l}\text { Control hyperlipidemic } \\
\text { with TR }\end{array}$ & $\begin{array}{c}116.5 \pm \\
2.058\end{array}$ & $\begin{array}{c}274.7 \pm \\
2.227\end{array}$ & $\begin{array}{c}191.9 \pm \\
3.032\end{array}$ & $\begin{array}{c}123.7 \pm \\
2.804\end{array}$ & $\begin{array}{c}228.5 \pm \\
2.197\end{array}$ & $\begin{array}{c}136.5 \pm \\
1.695\end{array}$ & $\begin{array}{c}19.38 \pm \\
0.884\end{array}$ & $\begin{array}{c}16.42 \pm \\
0.575\end{array}$ & $\begin{array}{c}21.24 \pm \\
0.481\end{array}$ & $\begin{array}{c}24.75 \pm \\
0.567\end{array}$ & $\begin{array}{c}45.69 \pm \\
0.439\end{array}$ & $\begin{array}{c}27.31 \pm \\
0.338\end{array}$ & $\begin{array}{c}72.37 \pm \\
1.056\end{array}$ & $\begin{array}{c}212.59 \pm \\
0.674\end{array}$ & $\begin{array}{c}143.35 \pm \\
0.721\end{array}$ \\
\hline Triton+ Simvastain & $\begin{array}{c}97.57 \pm \\
1.290^{* * * *}\end{array}$ & $\begin{array}{c}190.6 \pm \\
2,689^{* * *}\end{array}$ & $\begin{array}{c}92.37 \pm \\
1.958 * * *\end{array}$ & $\begin{array}{c}107.1 \pm \\
2.157^{* * *}\end{array}$ & $\begin{array}{c}189.5 \pm \\
1.361^{* * *}\end{array}$ & $\begin{array}{c}104.6 \pm \\
0.921^{* * *}\end{array}$ & $\begin{array}{c}32.29 \pm \\
1.097^{* * *}\end{array}$ & $\begin{array}{c}24.84 \pm \\
1.482 * * *\end{array}$ & $\begin{array}{c}37.40 \pm \\
1.632^{* * *}\end{array}$ & $\begin{array}{c}21.42 \pm \\
0.431 * * *\end{array}$ & $\begin{array}{c}37.91 \pm \\
0.2722^{* * *}\end{array}$ & $\begin{array}{c}20.92 \pm \\
0.184 * * *\end{array}$ & $\begin{array}{c}43.86 \pm \\
0.678 * * *\end{array}$ & $\begin{array}{r}127.85 \pm \\
0.867 * * *\end{array}$ & $\begin{array}{r}34.05 \pm \\
1.875^{* * *}\end{array}$ \\
\hline Triton + Alcohlic $150 \mathrm{mg} / \mathrm{kg}$ & $\begin{array}{l}107.3 \pm \\
0.881^{* *}\end{array}$ & $\begin{array}{l}220.5 \pm \\
0.991^{* *}\end{array}$ & $\begin{array}{c}122.8 \pm \\
1.537^{* * * *} \\
\end{array}$ & $\begin{array}{l}116.2 \pm \\
1.692^{*} \\
\end{array}$ & $\begin{array}{l}205.8 \pm \\
1.352^{* *}\end{array}$ & $\begin{array}{l}117.0 \pm \\
1.880^{* * * *}\end{array}$ & $\begin{array}{l}24.33 \pm \\
0.977^{* *} \\
\end{array}$ & $\begin{array}{l}22.33 \pm \\
0.802 * \\
\end{array}$ & $\begin{array}{l}28.47 \pm \\
1.582^{* *}\end{array}$ & $\begin{array}{l}23.24 \pm \\
0.338^{*} \\
\end{array}$ & $\begin{array}{c}41.23 \pm \\
0.2681^{* *} \\
\end{array}$ & $\begin{array}{l}23.47 \pm \\
0.381 * *\end{array}$ & $\begin{array}{l}59.33 \pm \\
0.234 * \backslash \\
\end{array}$ & $\begin{array}{l}157.04 \pm \\
1.034^{* *}\end{array}$ & $\begin{array}{c}71.4 \pm \\
1.628^{* *} \\
\end{array}$ \\
\hline Triton+ Alcohlic $300 \mathrm{mg} / \mathrm{kg}$ & $\begin{aligned} 105.7 \pm \\
1.453^{* * *}\end{aligned}$ & $\begin{array}{r}208.8 \pm \\
1.662^{* * * *}\end{array}$ & $\begin{array}{c}114.3 \pm \\
1.357^{* * * *}\end{array}$ & $\begin{array}{l}113.4 \pm \\
1.841^{* *}\end{array}$ & $\begin{aligned} 198.3 \pm \\
1.229^{* * * *}\end{aligned}$ & $\begin{array}{r}110.2 \pm \\
1.493^{* * * *}\end{array}$ & $\begin{array}{c}27.21 \pm \\
1.097^{* * * *}\end{array}$ & $\begin{array}{l}23.33 \pm \\
1.498^{* *}\end{array}$ & $\begin{array}{r}32.08 \pm \\
0.804 * * *\end{array}$ & $\begin{array}{c}22.67 \pm \\
0.3683^{* *}\end{array}$ & $\begin{array}{c}39.76 \pm \\
0.2469 * * *\end{array}$ & $\begin{array}{r}22.12 \pm \\
0.305^{* * *}\end{array}$ & $\begin{array}{c}55.82 \pm \\
1.043^{* * *}\end{array}$ & $\begin{array}{r}145.71 \pm \\
0.934^{* * * *}\end{array}$ & $\begin{aligned} 60.17 \pm \\
.0737 * * *\end{aligned}$ \\
\hline $\begin{array}{c}\text { Triton } 1+\text { Aqueous } \\
150 \mathrm{mg} / \mathrm{kg}\end{array}$ & $\begin{array}{l}110.2 \pm \\
1.537^{*} \\
\end{array}$ & $\begin{array}{l}262.8 \pm \\
1,851^{*} \\
\end{array}$ & $\begin{array}{c}181.7 \pm \\
1.542 * * \\
\end{array}$ & $\begin{array}{l}116.1 \pm \\
1.477^{*}\end{array}$ & $\begin{array}{l}219.0 \pm \\
1.734^{*}\end{array}$ & $\begin{array}{c}127.8 \pm \\
1.662^{* * *} \\
\end{array}$ & $\begin{array}{l}23.47 \pm \\
1.112 * \\
\end{array}$ & $\begin{array}{l}21.17 \pm \\
1.701^{*}\end{array}$ & $\begin{array}{c}27.19 \pm \\
1.010^{* *} \\
\end{array}$ & $\begin{array}{l}23.23 \pm \\
0.295^{*} \\
\end{array}$ & $\begin{array}{l}43.80 \pm \\
0.346^{*}\end{array}$ & $\begin{array}{l}25.69 \pm \\
0.335^{*}\end{array}$ & $\begin{array}{c}63.5 \pm \\
0.896^{*} \\
\end{array}$ & $\begin{array}{l}197.77 \pm \\
1.341^{* *}\end{array}$ & $\begin{array}{c}128.82 \pm \\
0.943 *\end{array}$ \\
\hline $\begin{array}{c}\text { Triton + Aqueous } \\
300 \mathrm{mg} / \mathrm{kg}\end{array}$ & $\begin{array}{l}109.01 \pm \\
1.183^{* *}\end{array}$ & $\begin{array}{r}239.5 \pm \\
1.893^{* *}\end{array}$ & $\begin{array}{c}145.7 \pm \\
1.282 * * * \\
\end{array}$ & $\begin{array}{r}114.4 \pm \\
1.453^{* *}\end{array}$ & $\begin{array}{r}207.5 \pm \\
1.746^{* *}\end{array}$ & $\begin{array}{c}120.2 \pm \\
1.579^{* * * *} \\
\end{array}$ & $\begin{array}{c}24.56 \pm \\
0.824^{* *}\end{array}$ & $\begin{array}{l}20.83 \pm \\
0.703 *\end{array}$ & $\begin{array}{c}29.51 \pm \\
1.175^{* * * *}\end{array}$ & $\begin{array}{r}22.89 \pm \\
0.286^{* *}\end{array}$ & $\begin{array}{c}41.58 \pm \\
0.358^{* *}\end{array}$ & $\begin{array}{r}24.12 \pm \\
0.335^{* *}\end{array}$ & $\begin{array}{r}61.56 \pm \\
0.560^{* *} \\
\end{array}$ & $\begin{array}{r}177.09 \pm \\
0.459^{* * * *}\end{array}$ & $\begin{array}{c}90.5 \pm \\
0.592^{* *}\end{array}$ \\
\hline
\end{tabular}

$* \mathrm{P}<0.05, * * \mathrm{P}<0.01,{ }^{* * *} 0.001$, when compared with control (Dunnett's t-test after analysis of variance). Results are mean \pm SEM $(\mathrm{n}=6)$

TC : total cholesterol ; TG : Triglycerides ; HDL : High Density Lipoproteins ; VLDL : Very Low Density Lipoproteins ; LDL : Low Density Lipoprotein

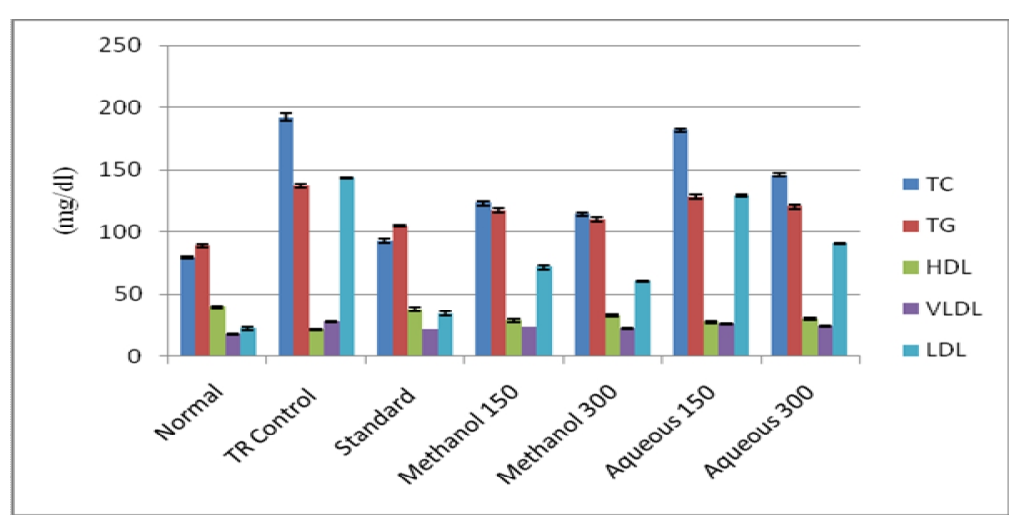

Figure 1: Effect of alcoholic and aqueous extracts of stem of Suaeda maritima (L.) Dumort. on lipid profile in Triton induced hyperlipidemic rats after 48 hours

$* \mathrm{P}<0.05, * * \mathrm{P}<0.01, * * * 0.001$, when compared with control (Dunnett's t-test after analysis of variance). Results are mean $\pm \mathrm{SEM}(\mathrm{n}=6)$ 


\section{Preparation of Doses}

Simvastatin (Ranbaxy, India) $10 \mathrm{mg} / \mathrm{kg}$ was taken as standard drug for hypolipidemic activity. The methanol extract $150 \mathrm{mg} / \mathrm{kg}$ and $300 \mathrm{mg} / \mathrm{kg}$ was prepared in $1 \%$ Tween 80 . Aqueous extract $150 \mathrm{mg} / \mathrm{kg}$ and $300 \mathrm{mg} / \mathrm{kg}$ was prepared in distilled water. The stock solution of standard was prepared in normal saline.

\section{Experimental Animals}

Wistar rats of either sex (weighing 100-150g) were used. The experimental protocols were approved by Institutional Animal Ethical Committee, Guru Jambheshwar University of Science and Technology, Hisar vide Endst. No. 69-77 dated 04-01-2011. The animals were maintained under standard conditions $\left(25 \pm 2^{\circ} \mathrm{C}\right.$ and relative Humidity $50 \pm 5 \%$ and $12: 12$ hour day cycle).

\section{Induction of Hyperlipidemia}

Hyperlipidemia in rats was induced experimentally by single injection of triton WR-1339 (400 mg/kg b.w.). Triton was diluted with normal saline and injected $1 \mathrm{ml} / \mathrm{kg}$ b.w. to each rat intraperitoneally. ${ }^{13}$.

\section{Hypolipidemic Activity}

The animal were divided into 6 groups, each group consisting of 6 animals. The control group was injected with triton WR-1339 (400 mg/kg b.w.) intraperitoneally. The standard group was given simvastatin at the dose $10 \mathrm{mg} / \mathrm{kg}$ body weight. The methanol extract was administered at $150 \mathrm{mg} / \mathrm{kg}$ and $300 \mathrm{mg} / \mathrm{kg}$ body weight dose to $3^{\text {rd }}$ and $4^{\text {th }}$ group respectively. The aqueous extract was administered at $150 \mathrm{mg} / \mathrm{kg}$ and $300 \mathrm{mg} / \mathrm{kg}$ body weight dose to $5^{\text {th }}$ and $6^{\text {th }}$ group respectively. The dose were administered orally once daily in the morning. During the period of experiment the animals had free access to food and water. Twenty hour prior to the end of experiment food was withdrawn and blood samples were taken by retro-orbital puncture after 6 hours, 24 hours and 48 hours. The biochemical parameters of collected blood samples like serum total cholesterol, triglycerides, high density lipoproteins, low density lipoproteins and very low density lipoproteins were determined by using Autoanalyzer (Remi) (Table1).

\section{Statistical Analysis}

The data expressed as the mean \pm SEM. The results were compared with control group using ANOVA followed by student Dunnett's T test. The results were considered as statistically significant of $\mathrm{P} \leq 0.05$ when compared with control.

\section{RESULTS}

The present study was carried out to evaluate the hypolipidemic activity of methanol and aqueous extract of stem of Suaeda maritima. The aqueous extract at treated doses i.e. $150 \mathrm{mg} / \mathrm{kg}$ and $300 \mathrm{mg} / \mathrm{kg}$ body weight did not show any significant hypolipidemic activity. The methanol extract showed the significant activity when compared to control at $300 \mathrm{mg} / \mathrm{kg}$ dose as shown in Table 1 and Figure 1. There was a significant decrease in total cholesterol, triglyceride, low density lipoprotein, very low density lipoprotein and increase in high density lipoprotein as compared to control. The Suaeda maritima methanolic extract at dose $300 \mathrm{mg} / \mathrm{kg}$ body weight orally showed antihyperlipidemic activity.

\section{DISCUSSION AND CONCLUSION}

Despite significant medical advances, heart attack due to coronary artery disease and stroke are responsible for more deaths than all other causes combined. A $1 \%$ drop in serum cholesterol reduces the risk of cardiac heart disease by $2 \%{ }^{1}$. The increased blood level of total cholesterol, triglyceride, low density lipoprotein, very low density lipoprotein and Lowered level of High density lipoprotein has been identified in development of hyperlipidemia. The hypolipidemic allopathic drugs are available in market but the side effects and contraindication of these drugs have marred their popularity ${ }^{18}$. Recently herbal hypolipidemic drugs have gained importance to fill the lacunae created by the allopathic drugs.

Triton WR-1339 has been widely used to block clearance of triglyceride-rich lipoproteins to induce acute hyperlipidemia in several animals ${ }^{14}$. This model is widely used for a number of different aims ${ }^{15}$ particularly, in rats it has been used for screening natural or chemical hypolipidemic drugs. Interestingly, the results of the present study show that extract of Suaeda maritima produced a significant reduction in cholesterol level and also it reversed Triton induced hyperlipidemia in rats. The rats treated with triton exhibited significant increase in total cholesterol, triglyceride, low density lipoprotein, very low density lipoprotein and frequent decrease in high density lipoprotein ratio as compared to the normal. From obtained result it was observed that when triton treated rats was co-administered with methanol and aqueous extracts, the elevated levels of total cholesterol, triglyceride, low density lipoprotein, very low density lipoprotein condition has shown considerable decline. The activity of methanolic extract was more significant as compared to aqueous extract.

Simvastatin which was used as positive control in this study is a HMG-COA reductase inhibitor. Rats treated with simvastatin showed marked reduction in all serum lipoproteins and increase in high density lipoprotein level as compared with Triton treated group

The Suaeda maritima methanolic extract at dose $300 \mathrm{mg} / \mathrm{kg}$ body weight orally showed antihyperlipidemic activity which may be due to the presence of triterpenoids and sterols ${ }^{16-17}$ found in the preliminary phytochemical screening. Thus, these findings indicate that this plant may be useful for the treatment of hyperlipidemia.

\section{ACKNOWLEDGEMENTS}

The authors are thankful to Institutional Animal Ethical Committee for giving the permission to use experimental animal.

\section{REFERENCES}

1. Jain KS, Kathiravan MK, Somani RS and Shishoo CJ. The biology and chemistry of hyperlipidemia. Bioorganic \& Medical Chemistry, 2007; 15(14):46740-4699. http://dx.doi.org/10.1016/j.bmc. 2007.04.031 PMid:17521912

2. Third report of the National Cholesterol Education Program (NCEP) Expert Panel on detection, Evaluation and treatment of high blood cholesterol in adults(Adult treatment panel III) Final report, circulation, 2002; 106:3143.

3. Kaesancini Y.A. and Krauss M.R., Cardiovascular disease and hyperlipidemia. Cur. Opinion in lipidology. 1994; 5:249-251. 
4. Davey GS and Pekkanen J. Should there be a moratorium on the use of cholesterol lowering drugs? Br.Med.J. 1992; 304:431-440. http://dx.doi.org/10.1136/bmj.304.6824.431

5. Brown SL. Lowered serum cholesterol and low mood. J.Br.Med. 1996; 313:637-638. http://dx.doi.org/10.1136/bmj.313.7058.637

6. Speight TM and Avery's. Drug treatment: Principles and practice of clinical pharmacology and therapeutics. $3^{\text {rd }}$ edn. 559, Adis Press Ltd.,Auckland 1987.

7. Kaliora AC, Dedoussis GVZ and Schmidt H. Dietary antioxidants in preventing atherogenesis, Artherosclerosis 2006; 1:18.

8. Padmakumar K and Ayyakkannu K. Antiviral activity of marine plants. Indian J. Virol, 1997; 33:13.

9. Premanthan M, Chandra K, Bajpai SK and Kathiresan K. A survey of some Indian marine plants for antiviral activity. J Bot Mar, 1992; 35:321.

10. Magwa ML, Mazuru G, Nyasha G and Godfred H. Chemical composition and biological activities of essential oil from the leaves of Sesuvium portulacastrum. J Ethnopharmacol, 2000; 1(103):85.

11. Ghosh A, Misra S, Duta AK and Choudhary A. Pentacyclic triterpenoids and sterols from seven species of mangrove. Phytochem, 1985; 24:1725. http://dx.doi.org/10.1016/S00319422(00)82541-8

12. Subramanyam C, Rao KB, Rao CV and Rao BV. Chemical examination of Suaeda maritima. Acta Cien Indica, 1992; 18:7.

13. Schurr PE, Schultz JR, Parkinson TM. Triton induced hyperlipidemia in rats as an animal model for screening of hypolipiremic drugs. Lipids, 1972; 7:68-74. http://dx.doi.org/ 10.1007/BF02531272 PMid:5013174

14. Kellner A, Correll JW and Ladd AT. Sustained hyperlipidemia induced in rabbits by means of intravenously injected surface active agents. J.of.Exp.Medicine, 1951; 93:373-384. http://dx.doi.org /10.1084/jem.93.4.373 PMid:14824409 PMCid:2136077
15. Fiser RH, Denniston, Rindsig RB and Beisel WR. Triglyceride secretion rates: use of Triton in the rhesus monkey. J.of Nutr, 1974; 104:223-226.

16. Kothari S, Jain AK, Mehta S C and Topany SD. Hypolipidemic effect of fresh Triticum aestivum grass juice in hypercholesterolemic rats. Acta poloniae pharmaceutica:Drug research, 2011; 68(2):291-294,

17. Dhulasavant V, Shinde S, Pawar $M$ and Naikwade N.S Antihyperlipidemic activity of Cinnamomum tamala Nees on high cholesterol diet induced hyperlipidemia. I.J. of PharmTech research, 2010; 2(4):2517-2521

18. Sindhu R, Vasudeva N and Sharma SK. Hypolipidemic potential of ethanolic extract of verbesina encelioides Benth. roots. Acta poloniae pharmaceutica:Drug research, 2011; 68(2):301-304.

19. Singh S, Mann R, Sharma SK. Antihyperlipidemic activity of Suaeda maritima(L.) Dumortier aerial parts in hypercholesterolemic rats. J of Pharmacy research, 2012; 5(3):1400-1402.

20. Singh S, Mann R, Sharma SK. Phytochemical analysis and pharmacognostical standardization of stem of Cayratia trifolia (Linn.) Domin I J of Pharmaceutical Sciences and Research, 2012; 3(11):4503-4506.

21. Singh S, Sharma SK, Mann R. Pharmacognostical standardization of stem of Suaeda maritima (L.) Dumort. I J of Pharmacy \& Pharmaceutical Sciences, 2012; 4(3):304-306.

\section{Cite this article as:}

Rajinder Mann, Sumitra Singh and Surendra Kr. Sharma. Antihyperlipidemic activity of Suaeda maritima (L.) dumortier stem in Triton induced hyperlipidemic rats. Int. J. Res. Ayurveda Pharm. 2013; 4(2):203-206 